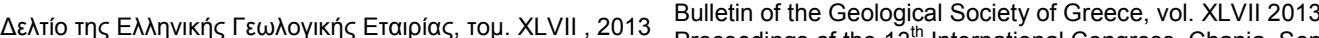
Proceedings of the $13^{\text {th }}$ International Congress, Chania, Sept.

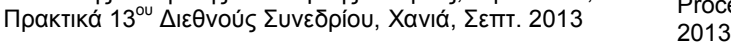

\title{
LATE QUATERNARY PALAEOENVIRONMENTAL CHANGES IN THE AEGEAN SEA: INTERRELATIONS AND INTERACTIONS BETWEEN NORTH AND SOUTH AEGEAN SEA
}

\author{
Kontakiotis G. ${ }^{1}$, Antonarakou A. ${ }^{1}$ and Zachariasse W.J. ${ }^{2}$ \\ ${ }^{I}$ National and Kapodistrian University of Athens, Faculty of Geology and Geoenvironment, \\ Department of Hist.Geology - Paleontology,gkontak@geol.uoa.gr, aantonar@geol.uoa.gr \\ ${ }^{2}$ Faculteit Aardwetenschappen, Universiteit Utrecht,wzachariasse@hetnet.nl
}

\begin{abstract}
The present study describes the Late Quaternary palaeoenvironmental evolution and the main palaeoceanographic changes of the Aegean Sea reconstructed using planktonic foraminifera. This approach, including $Q$-mode and R-mode cluster analyses, gives an insight into the relationships between sea surface environmental changes between north and south Aegean, and furthermore serves as a baseline data set for palaeoclimatic and palaeoceanographic reconstructions of the eastern Mediterranean Sea.

Key words: planktonic foraminifera, last glacial cycle, palaeoceanography, palaeoecological reconstruction, eastern Mediterranean.

\section{Пєрі́ $\eta \psi \eta$}

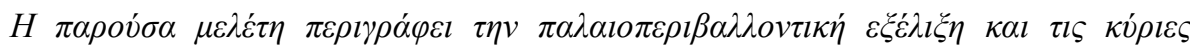

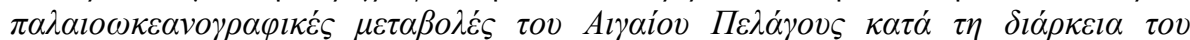

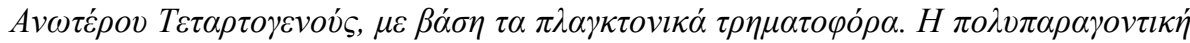

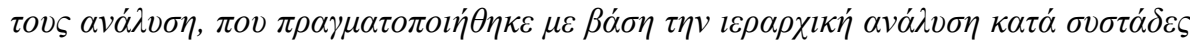

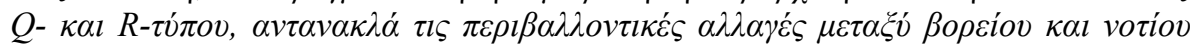

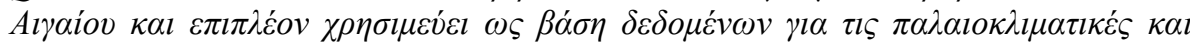

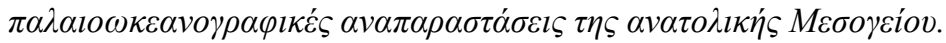

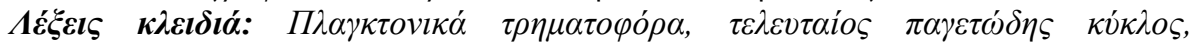

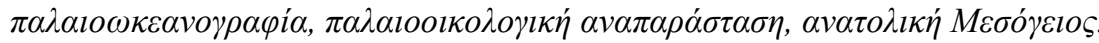

\section{Introduction}

The Aegean Sea has been the focus of intensive studies during the last half-century. The crucial importance of this small marginal basin is in its capability to register and amplify the smallest climatic variations occurring at the mid-latitude regions. The signals registered by changes in abundance and distribution of fossil micro-organisms, such as the planktonic foraminifera, represent one of the most powerful tools in many environmental reconstructions, and in the study area they provide a reliable and well-documented record at both global and local scales. They have proven to be reliable indicators in palaeoceanographic and palaeoclimatic studies, because they are seen as "fingerprints" of the water masses in which they live, behaving as indicators of temperature, salinity, and nutrient content and making it possible to identify past circulation 
through the sedimentary record (Kennett, 1982). The uses of sediment cores have confirmed the importance of the information obtained from the study of these organisms. Evidence is mainly provided by high-sedimentation cores from open-ocean areas. In the eastern Mediterranean, accumulation rates are generally low, and as a result, only a few studies have focused on the last 30.000 years (e.g. Geraga et al., 2005; Triantaphyllou et al., 2010). An exception is the Aegean Sea, an area with unusually high sedimentation rates, where a large number of high quality gravity cores have been recovered. Therefore in the present study, we focus our attention on the Aegean Sea and especially on the planktonic foraminifera retrieved from this area, which contribute to palaeoenvironmental reconstruction of the last glacial cycle.

\section{Materials and Methods}

\subsection{Study Sites}

We have studied two gravity cores (NS-40 and SK-1) along the Aegean Sea. Core SK-1 recovered during the R/V Discovery cruise of 1982 in the north-central Aegean Basin $\left(38^{\circ} 80^{\prime} \mathrm{N}\right.$ and $23^{\circ} 80^{\prime}$ E), at present day water depth of $1000 \mathrm{~m}$. The core NS-40 recovered during the R/V Aegaio cruise of 1998, from a similarly deep site (1078 $\mathrm{m}$ depth), at the easternmost edge of the recent Aegean volcanic arc in south Aegean Sea $\left(37^{\circ} 01^{\prime} \mathrm{N}\right.$ and $\left.26^{\circ} 19^{\prime} \mathrm{E}\right)$. Both cores consist of grey hemipelagic mud, intercalated with Santorini tephra layer Z2, the most recent sapropel S1 and turbidite layers (Zachariasse et al., 1997; Triantaphyllou et al. 2009; Kontakiotis, 2012). The established chronology of the cores NS-40 and SK-1 has led to an expanded palaeoecological reconstruction of the Late Glacial-Holocene archive in the Aegean Sea, spanning approximately the last $30 \mathrm{kyr}_{\mathrm{nc}} \mathrm{BP}$ and $16 \mathrm{kyr}_{\mathrm{nc}} \mathrm{BP}$ respectively (Kontakiotis, 2012).

\subsection{Micropalaeontological Analyses}

Detailed quantitative micropalaeontological analyses have been performed on 104 samples from the studied cores (55 from the core NS-40 and 49 from the core SK-1). After washing and drying at $60^{\circ} \mathrm{C}$, the samples were sieved through 150 and $63 \mu \mathrm{m}$ mesh. The $>150 \mu \mathrm{m}$ size fraction was split into aliquots, from which 300 specimens of planktonic foraminifera were picked, identified and counted following the taxonomic concept of Hemleben et al. (1989). For palaeoenvironmental reconstructions, Q-mode and R-mode cluster analyses have been performed on the data set, after exclusion of rare species $(<2 \%)$ and grouping of species that have a discontinuous, scattered distribution at generic level. Q-mode cluster analysis was used to determine the overall statistical similarity between samples. R-mode cluster analysis was performed in order to obtain a more accurate differentiation of the planktonic foraminiferal assemblages extracted from the Q-mode cluster analysis, into environmentally significant groups.

\subsection{Taxonomical Concept}

The quantitative analysis of the planktonic foraminifera identified follows a stable taxonomical concept in both cores, in order to establish a planktonic foraminiferal biostratigraphic framework for the studied sections and examine the changes in sea-surface conditions and climate. Species with phylogenetic affinities and similar ecological characteristics were counted together and grouped to better interpret distribution patterns.

We identified 23 species lumped into 17 groups according to the following modifications. The Globigerina bulloides group includes the species G. bulloides and G. falconensis, because they present the same ecological requirements. All morphotypes of G. ruber (G. ruber, G. elongatus, G. pyramidalis, kummerform type) are plotted together, distinguishing only the "alba" and "rosea" varieties due to different ecological characteristics. The Globigerinoides trilobus group includes $G$. trilobus and G. sacculifer type, using the taxonomic concept of Hemleben et al. (1989), and the Globigerinella siphonifera group includes the species Globigerinella aequilateralis, Globigerina calida and Globigerina digitata. Moreover, the species Globoturborotalita rubescens and 
Globoturborotalita tenella were counted and plotted together because of the similarity of their ecological characteristics (Capotondi et al., 1999). Furthermore, the species Globigerinita glutinata includes the morphotypes with and without bulla. Within the group of Neogloboquadriniids, two types have been discerned: $N$. pachyderma and $N$. dutertrei. Their different coiling directions have been counted and plotted separately, due to their different oceanographic requirements. Finally, the species $G$. sacculifer, $H$. pelagica, G. rubescens, $O$. universa, G. digitata, G. tenella, and G. siphonifera were grouped as SPRUDTS group (Rohling et al., 1993).

\section{Results and Discussion}

\subsection{Planktonic Foraminiferal Trends}

The faunal pattern of planktonic foraminiferal taxa for each core is plotted in Figures 1 and 2.

The G. ruber alba is abundant in north and south Aegean, being the main faunal constituent throughout the cores. Its maximum abundance occurs in the upper part of the cores and particularly during the deposition of sapropel S1. In the middle part of the cores, its distribution pattern is marked by a sharp increase in the abundance of G. ruber alba, corresponding to the last deglaciation. This is more pronounced in south Aegean (core NS-40). In the lower part of the cores, the distribution pattern of this species is limited, with the exception of the interval attributed to the Last Glacial Maximum. The distribution pattern of G. ruber rosea is characterized by high percentages in the upper part of both cores, with its maximum percentages to occur during the deposition of sapropel S1 and then decreasing gradually. This species is totally absent during the glacial period. Globigerina bulloides is continuously present, displaying almost the same distributional pattern in both cores. It reaches higher abundance values mostly in the upper part of the cores (Holocene) and in the lower part corresponding to the glacial period. It is worth noting the elevated percentages of G. bulloides in north Aegean during the deposition of the sapropel S1, which are attributed to a combination of increased river outflow and flushing of the Black Sea due to restored inflow of saline Mediterranean water at that time (Zachariasse et al., 1997). The $G$. trilobus-sacculifer group totally disappears within the glacial period, existing only in the upper part of the cores. More explicitly, its relative abundance curve displays a highly variable downcore pattern during the Holocene, occasionally reaching significant percentages during the deposition of S1. O. universa displays a sporadic distribution pattern being more abundant in the upper part of the cores. It shows several peaks in abundance during the deposition of S1, while it is almost absent in the lower part of the core, with its restricted occurrence in small percentages during the transition from the Late Glacial to the Holocene. The distributional pattern of G. rubescens is comparable with the relevant pattern of $G$. siphonifera, showing an overall upward increase. Moreover, the latter species shows a more sporadic distribution pattern than the former. On the contrary, G. glutinata displays a highly variable downcore pattern. It presents a continuous distribution in the core NS-40, with its maximum percentage values to occur in the middle and the lower part of the core, and a more sporadic distribution pattern in the core SK-1. T. quinqueloba is discontinuously present in both cores, occurring mostly in the lower part of the cores. During the Holocene, it displays a differential distributional pattern, since it mostly occurs below and above sapropel deposition and within the interruption in the core NS-40 and within the sapropel S1 in the core SK-1. In core NS-40, G. inflata reaches maximum abundance immediately above and below the deposition of, within the interruption of sapropel, as well as within the middle part of the core. In core SK-1 its occurrence is restricted at the end of S1, where it displays pronounced high values. G. scitula displays the same distribution pattern, existing in small percentages in the lower part of the cores, with only slight influxes to be recorded during the Younger Dryas (core SK-1) and the Holocene (upper part of S1a -core NS-40). Groborotalia truncatulinoides is present only in core NS-40, where it mainly restricted at the lower part of the core. Neogloboquadriniids, represented by $N$. pachyderma and $N$. dutertrei, are absent in the sapropel intervals. During the Holocene, they mainly occur within the interruption and above the sapropel interval. On the contrary, these 
species are abundant during the glacial period, being the main faunal constituent (Geraga et al., 2005). However, $N$. pachyderma and $N$. dutertrei sinistrally coiled specimens, show significant influxes in the lower part of the core NS-40, which can be attributed to Heinrich events.

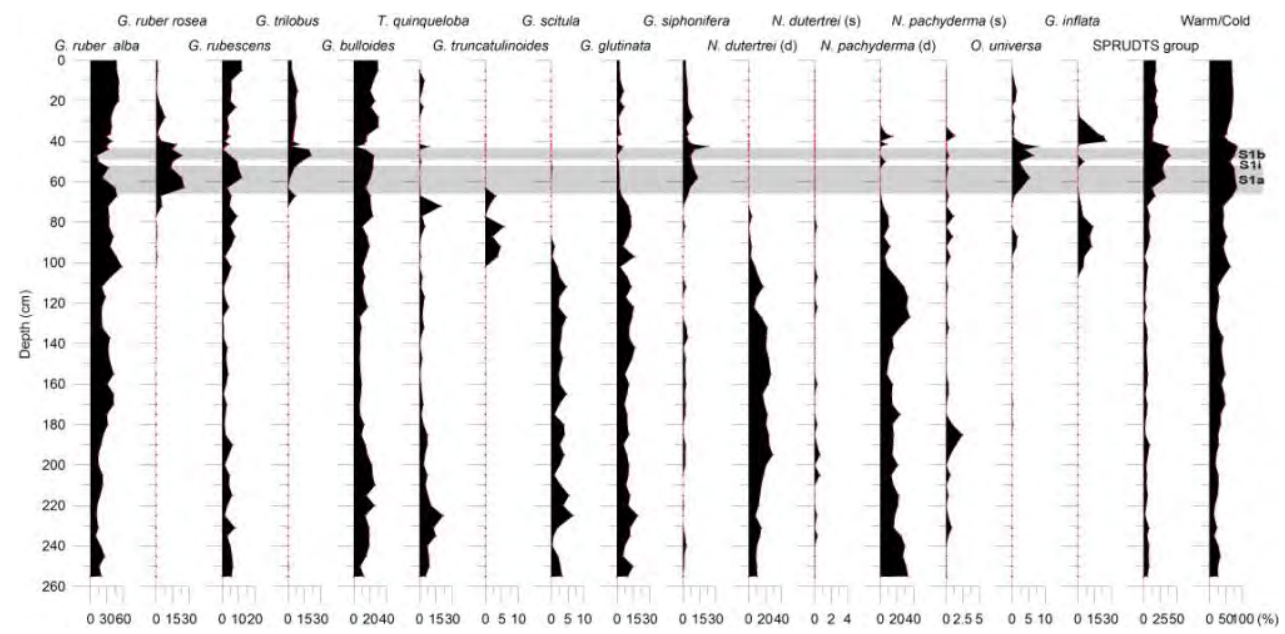

Figure 1 - Frequency curves of the most indicative planktonic species in core NS-40.

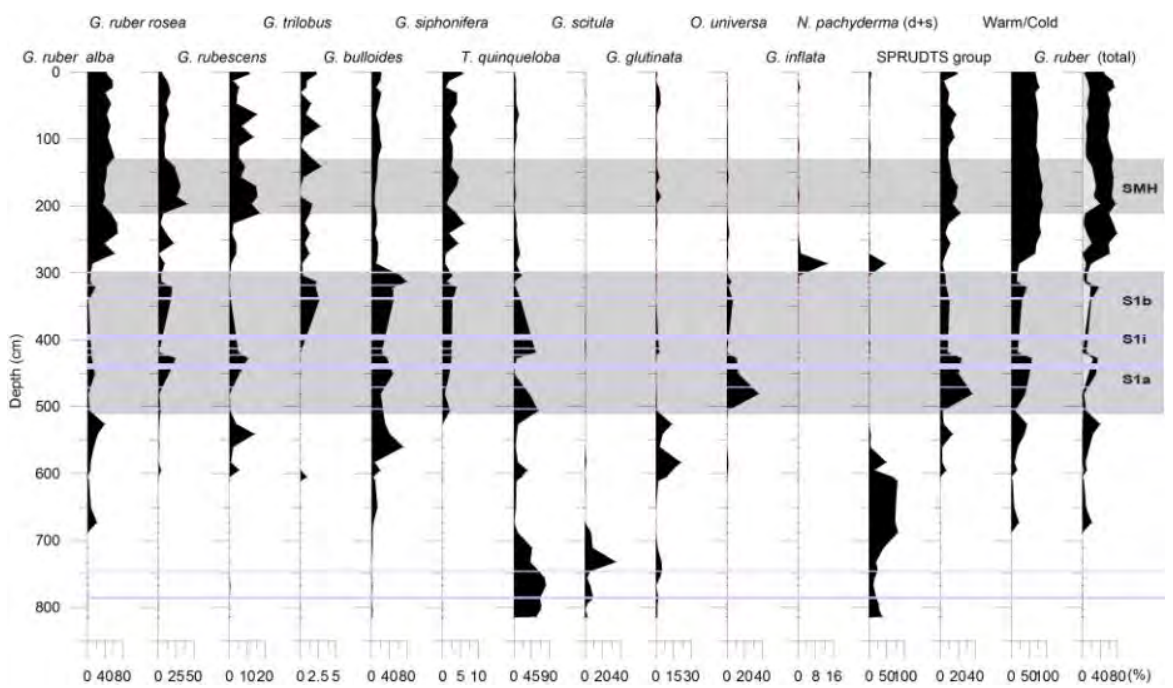

Figure 2 - Frequency curves of the most indicative planktonic species in core SK-1.

\subsection{Planktonic Foraminiferal Assemblages}

\subsubsection{Q-mode Cluster Analysis}

In order to describe the faunal succession, the samples of each core were treated with Q-mode cluster analysis to discriminate critic patterns in planktonic foraminiferal assemblages. Four and three distinct assemblages of planktonic foraminifera were identified by Q-mode cluster analysis in north and south Aegean respectively, reflecting different biotopes during the Late Quaternary (Figure 3 and 4). Each assemblage is characterized by dominant species as follows:

- South Aegean (Figure 3):

- Biotope I (Assemblage Neogloboquadriniids): It contains 29 samples (OS27-OS56) and represents the lower part $(107-255 \mathrm{~cm})$ of the core NS-40 corresponding to the glacial period. This assemblage is dominated by individuals of neogloboquadriniids ( $\mathrm{N}$. 
pachyderma and N. dutertrei) (26.33-51.08\%, average 38.71\%) and separated into two sub-assemblages depending on the principal representative species $\mathrm{N}$. dutertrei (assemblage IA) or the species N. pachyderma (assemblage IB). The next abundant species is G. ruber (9.73-42.24\%, average $25.98 \%$ ), with its high abundance to be representative of the interglacial intervals. The third most abundant species is G. glutinata $(5.37-18.88 \%$, average $12.13 \%$ ), while the species $\mathrm{T}$. quinqueloba also has a significant presence in this assemblage (1.00 to $21.28 \%$, average $11.14 \%$ ). The species G. scitula (0.34-6.65\%, average $3.45 \%$ ) and G. rubescens $(0.62-6.48 \%$, average $3.55 \%)$ are also involved in lower percentages. It is also noteworthy the variability of the species G. bulloides, with its percentages to range from 7.16 to $25.59 \%$ (average $16.37 \%$ ). This biotope is characterized by the seasonal thermal stratification of surface waters (glacial-interglacial periods) (Kontakiotis, 2012). The latter consists of the development of a warm mixed layer, which is accompanied by expansion of the thermocline during interglacial periods, as opposed to the abrupt reversal of the water column in cooler glacial intervals.

- Biotope II (Assemblage G. ruber alba-G. inflata-G. bulloides): It contains 26 samples (OS1-OS10, OS16, OS19-OS26) and represents sporadic parts of the core, at different periods, reflecting transitional assemblages. The first and the third branch (samples OS1-OS10, OS16, OS19) correspond to sub-assemblage IIA and IIГ reflecting the modern water column of the southern Aegean, while the second branch (samples OS21 OS25) corresponds to the sub-assemblage IIB which is indicative of the deglaciation. This assemblage is dominated by the species G. ruber alba (11.60-57.19\%, mean $34.4 \%$ ) and G. bulloides (10.40-29.86\%, average 20.13\%), and contains both cold and warm water indicators. Its subdivision on each one of the three sub-assemblages depends on the presence or absence of temperate species (G. inflata, N. pachyderma, G. truncatulinoides). The sub-assemblage IIA is dominated by the species G. ruber alba and G. inflata. The abundance of the species G. bulloides and N. pachyderma is also significant. The relative abundance primarily in G. ruber alba and additionally in $\mathrm{N}$. pachyderma implies strongly stratified surface and subsurface waters in the south Aegean Sea. In contrast, the high relative abundance of $G$. inflata and the significant presence of $\mathrm{G}$. bulloides exhibit an isothermal and homogeneous water column (Coulbourn et al., 1980), as a result of the strong vertical mixing. However, their coexistence highlights the strong seasonal contrasts governing this sub-assemblage. The sub-assemblage IIB is characterized by the prevalence of the species G. ruber alba (33.80-47.11\%, average $40.46 \%$ ) and the simultaneous significant presence of species such as G. bulloides (10.40-23.10\%, average 16.75\%), G. inflata (4.51-13.60\%, average $9.05 \%)$, N. pachyderma (5.06-11.59\%, average $8.32 \%)$, G. glutinata $(5.54-15.81 \%$, average $10.68 \%)$, G. truncatulinoides $(0-5.60 \%$, average $2.80 \%)$, indicating a mesotrophic environment. This transitional fauna corresponds to the transition from cold and eutrophic water column of the glacial period in warm oligotrophic water column of the Holocene. The sub-assemblage II $\mathrm{T}$ is characterized by the prevalence of G. bulloides (19.87-29.86\%, average $24.67 \%$ ) versus G. inflata (almost absent), and by the maintenance of the species G. ruber alba at the same high levels $(33.12-51.94 \%$, average $42.53 \%$ ), indicating an oligotrophic-mesotrophic environment with strong seasonal fluctuations.

- Biotope III (Assemblage G. ruber alba-Sprudts group-G. bulloides): It contains 7 samples (OS11-OS15 and OS17-OS18) representing the deposition of the most recent sapropel S1. This assemblage is mainly dominated by species representative of warm and oligotrophic waters (G. ruber alba, G. ruber rosea, G. trilobus, G. siphonifera, O. universa), and furthermore shows a significant reduction in the relative percentages of $\mathrm{G}$. bulloides, compared to previous biotopes. 


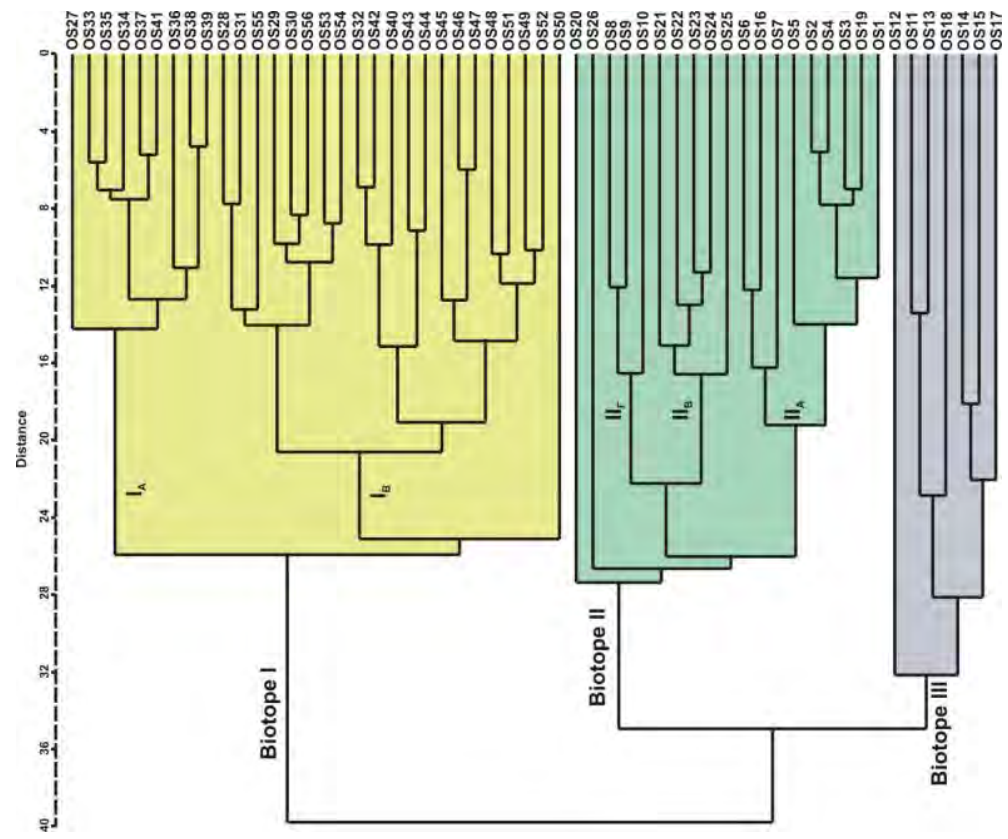

Figure 3 - Dendrogram resulting from Q-mode cluster analysis and the biotopes identified in core NS-40 (south Aegean).

\section{- North Aegean (Figure 4):}

- Biotope I (Assemblage G. bulloides): It contains 9 samples (SK22-SK25, SK27-SK28 and SK32-SK33) representing the deposition of the most recent sapropel S1. The species G. bulloides plays dominant role in it, with its percentages reaching up to $80 \%$ of the total fauna. This species is living at the surface or subsurface waters and withstands large fluctuations in temperature, salinity and density (stratification) of the water column, without being limited from these physical parameters (Rohling et al., 1993, 1997). Particularly, the elevated percentages during the deposition of sapropel highlight the activity of neighboring rivers and therefore reflect a stratified water column. This finding is supported by the significant presence of the species $\mathrm{T}$. quinqueloba, and O. universa, which have been associated with the reduced surface salinity conditions during the deposition of sapropel S1 (Zachariasse et al., 1997). However, the faunal composition of this assemblage indicates that the stratification of the water column is not limited to the surface, but it is continuous throughout the water column. G. ruber rosea is an indicator of maximum stratification of the water column and furthermore, the species G. siphonifera and Orbulina universa have the ability to live at greater depths during the summer, when the euphotic zone is strongly stratified. Thus, an increase in the abundance of all these species can be interpreted as an indication of the increase of the depth and the extent of the thermocline.

- Biotope II (Assemblage G. ruber alba-SPRUDTS group-G. bulloides): It contains 20 samples (SK1-SK20) and represents the upper part of the core $(0-271 \mathrm{~cm})$. This assemblage is mainly characterized by the prevalence of both varieties of the species $\mathrm{G}$. ruber. Also abundant are the species belonging to the SPRUDTS group, with G. rubescens to be their main component $(3.70-22.59 \%$, average $13.15 \%)$. Next in abundance species is G. bulloides (6.42-22.02\%, average $14.22 \%$ ), but significantly lower compared to the previous assemblage. This assemblage is divided into three individual sub-assemblages, which show remarkable seasonal contrasts in temperature (sub-assemblage IIA), productivity (sub-assemblage IIB) and stratification of the water 
column (sub-assemblage IIГ), depending on the relative abundances of species involved. In sub-assemblage IIA the high percentages $(>60 \%)$ of G. ruber alba combined with the maximum concentrations of the species T. quinqueloba reveal the seasonal, in terms of temperature, development of the stratified water column. In sub-assemblage IIB, the simultaneous presence of oligotrophic (G. ruber alba, G. ruber rosea, G. rubescens, G. trilobus/sacculifer group, O. universa and G. siphonifera) and eutrophic (G. bulloides, N. pachyderma, T. quinqueloba and G. glutinata) species certifies the seasonal contrast according to the available food supply, which characterizes this sub-assemblage. The factor of seasonality is also reinforced by the continuous presence (even in small amounts; $0.20-3.90 \%$, average $2.05 \%$ ) of G. glutinata, since this species can survive both in oligotrophic surface, and in more eutrophic waters by changing its diet from diatoms to crysophytes (Hemleben et al., 1989). Finally, in sub-assemblage IIC the significantly high percentages of the species belonging to the SPRUDTS group, and the presence of the species G. inflata and N. pachyderma (Hemleben et al., 1989; Rohling et al., 1993, 1997) allow us to assess the role of water column stratification.

- Biotope III (Assemblage Neogloboquadriniids): It contains 7 samples (SK21, SK34 and SK36-SK40) and represents the middle part of the core, which corresponds mostly to the transition from glacial to Holocene period. This assemblage is characterized by the predominance of neoglobo-quadriniids (47.24-81.28\%, average $64.26 \%$ ). The fauna complement the species T. quinqueloba $(0.96-19.47 \%$, average $10.21 \%)$, G. bulloides (1.70-12.61\%, average $7.16 \%)$, G. glutinata (0-20.70\%, average $10.35 \%)$, G. inflata (0$13.20 \%$, average $6.60 \%$ ) and $\mathrm{G}$. ruber alba $(0-21.22 \%$, average $10.61 \%)$. All these species present strong variations in their distribution pattern. Overall, this assemblage implies the existence of a mesotrophic to eutrophic, low-salinity environment. Furthermore, it should be noted that the relatively low percentages of G. ruber alba (compared to the same period covered by the same assemblage in the southern Aegean) are indicative of a cooler water column, which means that the transition from the glacial period to the Holocene was more abrupt in the north than in the south Aegean Sea.

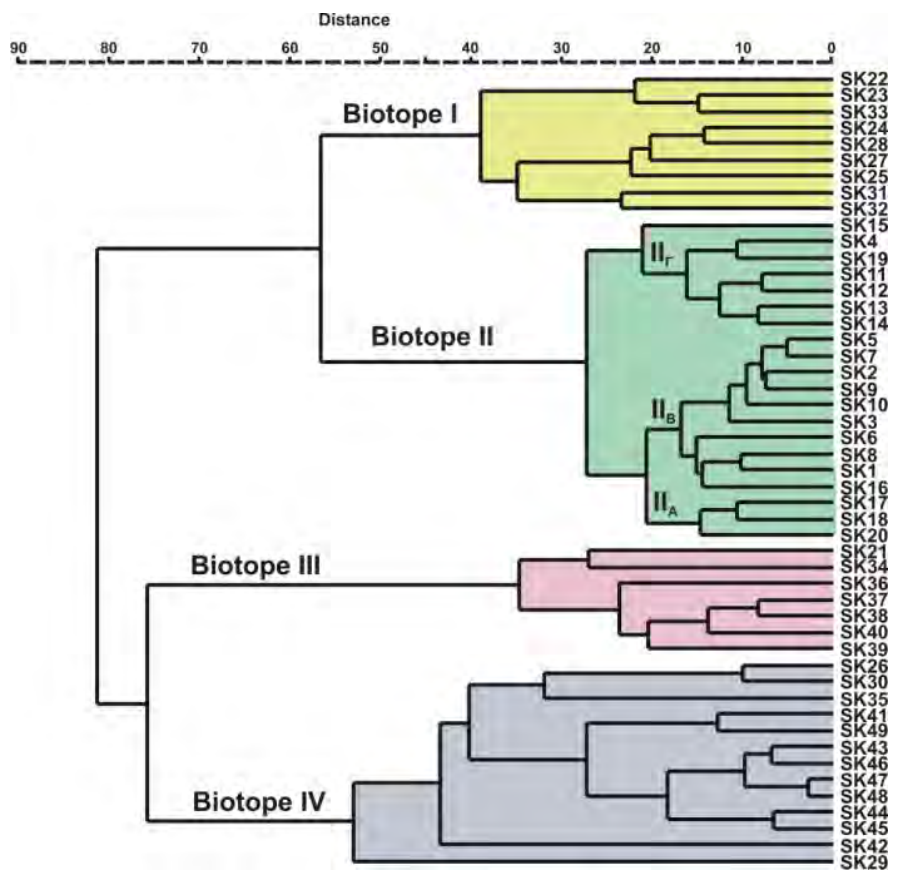

Figure 4 - Dendrogram resulting from Q-mode cluster analysis and the biotopes identified in core SK-1 (north Aegean).

XLVII. No $1-173$ 
- Biotope IV (Assemblage T. quinqueloba-Neogloboquadriniids): It contains 13 samples (SK26, SK29-SK30, SK35 and SK41-SK49), the majority of which represent the lower part of the core corresponding to the glacial period. It also includes the parts indicative of increased productivity and low salinity within the sapropel S1. The principal denominator in both cases of the north Ae-gean Sea is the dominance of the species T. quinqueloba (33.50-80.76\%, average $57.13 \%$ ). How-ever, within the glacial period, it is remarkable the high percentages of the Neogloboquadriniids (11.16-40.61\%, mean $25.89 \%$ ). Their high abundance in combination with the lower percentages of other cold-water species (e.g. G. scitula; $0.50-35.00 \%$ ) reflect the presence of particularly cold and eutrophic water masses in the north Aegean Sea. Moreover, the lower response of neoglobo-quadriniids in northern compared to the southern Aegean Sea indicates the weakening of the Deep Chlorophyll Maximum that can be locally linked to the deepening of the pycnocline/noutrocline below the euphotic zone.

\subsubsection{R-mode Cluster Analysis}

R-mode cluster analysis was also performed in order to obtain a more accurate differentiation of the planktonic foraminiferal assemblages extracted from the Q-mode cluster analysis, into environmentally significant groups. Inspection of the R-mode cluster analysis dendrograms (Figure 5 and 6) allows the identification of 3 planktonic foraminiferal groupings for south Aegean and 2 for the north Aegean Sea.

\section{- South Aegean (Figure 5):}

- Group A consists of the species G. trilobus, G. ruber rosea, G. siphonifera and O. universa indi-cating a warm and strongly stratified water column, which characterizes most of the Holocene, and especially the period of sapropel S1 deposition. Their abundance is mainly controlled (beyond temperature) by the stratification of the water column (Rohling et al., 1997), which varies depend-ing on the degree of development and the extent of the thermocline. This layer is essentially sepa-rating the species typical of warm and oligotrophic waters from those of cool and eutrophic waters. During the deposition of sapropel, as well as before and after this, the species G. ruber rosea and G. trilobus play the dominant role in fauna. They occur close to the surface, where there are the maximum levels of solar radiation and specifically into the low fertility mixed layer, which charac-terizes a strong vertical stratification of surface waters during the summer months (Hemleben et al., 1989). Similarly, the other species of this group live above the thermocline in a warm and well stratified water column (Rohling et al., 1993). Therefore, we interpret this group as indicative of the total area occupied by the layer of the thermocline.

- Group B consists of the species T. quinqueloba, G. scitula, G. glutinata, N. pachyderma, N. duter-trei, G. bulloides, G. ruber alba and G. rubescens, which can be considered typical of the condi-tions prevailing during the glacial period. However, the ecological correlations between them al-low the additional separation of the last three species from the remaining species of this group, resulting in the sub-division of group B into two distinct sub-groups. Specifically, the first five species characterize very cold waters and increased productivity, while the last three species char-acterize less cold and mesotrophic-eutrophic waters. Therefore, we interpret the first sub-group as indicative of glacial intervals (stadials) and the second sub-group as indicative of interglacial periods (interstadials) during the glacial period.

- Group C consists of the species G. inflata and G. truncatulinoides, indicating a homothermal water column throughout the euphotic zone, as a consequence of the strong convective mixing. Particularly, G. inflata prefers isothermal water masses (Coulbourn et al., 1980) during the winter or mesotrophic environments (Pujol \& Vergnaud-Grazzini, 1995). In these nutrient-rich mixed waters, it prefers to live in the 
deeper levels of the water column $(50-150 \mathrm{~m})$, whereas in mesotrophic environments they live in the upper $50 \mathrm{~m}$ of the water column. Specifically, during early summer where the stratification begins and DCM is absent, it lives below the seasonal thermocline, while in periods where the DCM is developed it lives in it. Moreover, it is indicative of horizontal exchange of water masses across the Mediterranean basin, with its high percentages in the western Mediterranean to reflect the influx of Atlantic waters and its low percentages in the eastern Mediterranean, to demonstrate the minor water exchange between the above sub-basins (Pujol \& Vergnaud-Grazzini, 1995). Moreover, the coexistence of the temperate species G. truncatulinoides indicates the presence of intermediate to the previous two groups water masses, with the intense action of Levantine Intermediate Waters (LIW) in the basin of the south Aegean and Eastern Mediterranean in general (Rohling et al., 1997).

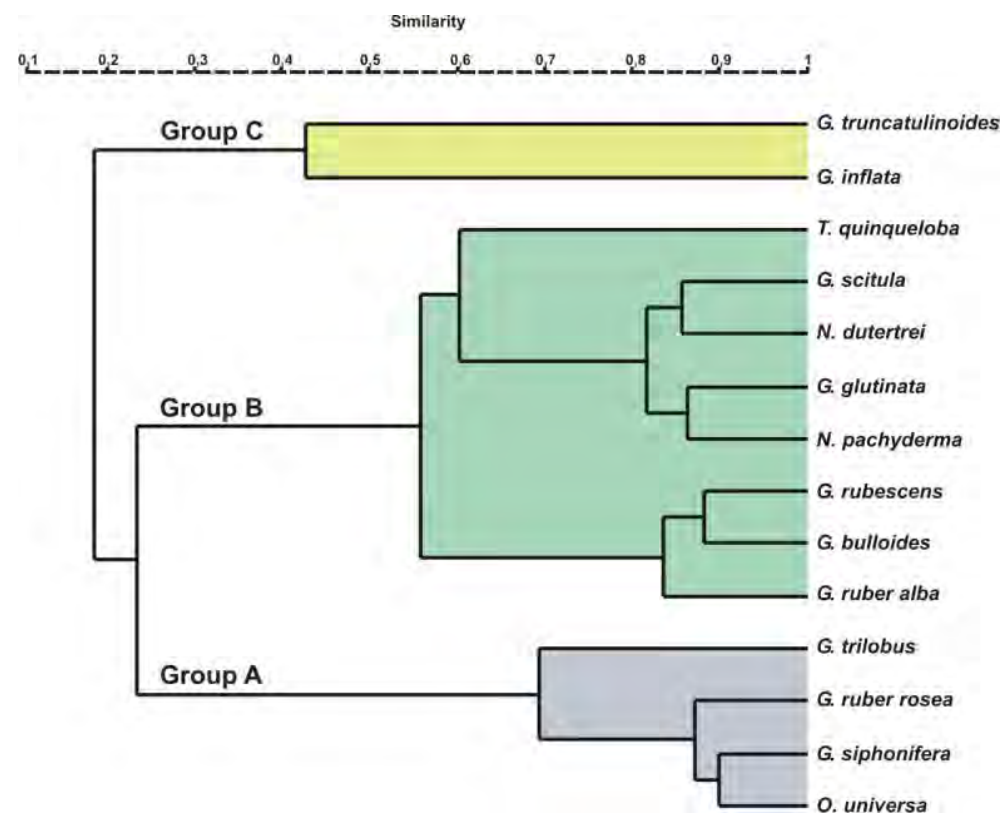

Figure 5 - Dendrogram resulting from R-mode cluster analysis and the assemblages identifie d in core NS-40 (south Aegean).

\section{- North Aegean (Figure 6):}

- Group A is characterized by warm and oligotrophic water indicators, including the species G. ruber alba, G. ruber rosea, G. trilobus, O. universa, G. siphonifera, G. rubescens and G. bulloides. These species (with the exception of G. bulloides) often referred to the literature as «SPRUDTS group» (Jorissen et al., 1993; Rohling et al., 1993); this group is indicative of the deposition conditions of the most recent sapropel $\mathrm{S} 1$ and have been recorded in various Mediterranean regions (including the Aegean Sea). However, this group seems to characterize the water column of the north Aegean throughout the Holocene, culminating in the post-sapropel period where they reach their maximum percentages. The difference with the corresponding group (group A) of the core NS-40 is due to the incorporation of G. bulloides, which has the ability to live in various environments, by extracting its favor trophic elements from the water column (Rohling et al., 1997). Its capacity, to move vertically and migrate to different water depths, depending on the available food supply every season, offers it the opportunity to live all year round, justifying thus the strong seasonal contrasts governing modern water column of the north Aegean Sea. 
- Group B is characterized by eutrophic, cold water indicators and includes the species N. pachyderma, N. dutertrei, T. quinqueloba, G. scitula and G. glutinata. This group also includes the temperate, mesotrophic species G. inflata and G. truncatulinoides, which reflect transitional conditions prevailing in north Aegean after the termination of the glacial period. Their co-existence in the same group shows that the conditions prevailing at the end of the glacial period in the northern Aegean, although improved, did not change significantly. This means that the transition from the glacial period to the Holocene period was not as gradual as in south Aegean.

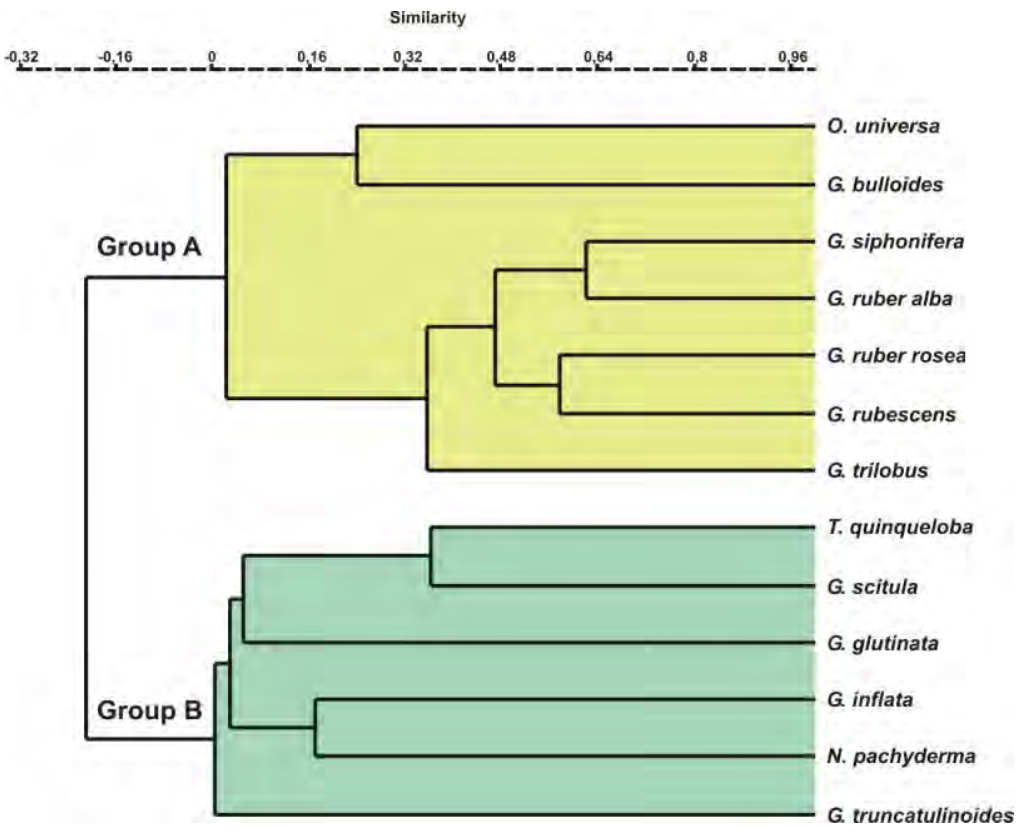

Figure 6 - Dendrogram resulting from $R$ -

mode cluster analysis and the assemblages identified in core SK-1 (north Aegean).

\section{Conclusions}

This study highlights the planktonic foraminiferal abundance variations during the last glacial cycle from two gravity cores (SK-1 and NS-40) along a north-south transect in the Aegean Sea. Qmode multivariate cluster analysis describes four and three distinct assemblages of planktonic foraminifera in north and south Aegean respectively. The succession of assemblages allows dividing Late Quaternary sediments into four palaeoceanographic stages: 1) a warm-oligotrophic stage (typical of Holocene) characterized by the prevalence of Globigerinoides ruber albaSPRUDTS group-Globigerina bulloides, 2) upwelling and runoff-low salinity conditions dominated by Globigerina bulloides, 3) a relatively warm to temperate with seasonal contrasts on temperature, productivity and stratification of the water column stage characterized by the Globigerinoides ruber alba, Globorotalia inflata and Globigerina bulloides, 4) a cool-eutrophic stage characterized by Neogloboquadriniids and Turborotalita quinqueloba. According to their stratigraphic distribution, the first and the second assemblages are typical for the deposition of sapropel S1 in south and north Aegean respectively, while the third is referring as a transitional assemblage of the last glacial-interglacial transition and the fourth one is corresponding to the last glacial period. 


\section{Acknowledgments}

The authors are grateful to Associate Professor M. Triantaphyllou for providing part of the study material (core NS-40). Dr. Theodora Tsourou is also warmly thanked for her constructive suggestions during the processing of the images.

\section{References}

Capotondi L., Borsetti A.M. and Morigi C. 1999. Foraminiferal ecozones, a high resolution proxy for the Late Quaternary biochronology in the central Mediterranean Sea, Mar. Geol., 153, 253-274.

Coulbourn W.T., Parker G.L. and Berger W.H. 1980. Faunal and solution patterns of planktonic foraminifera in surface sediments of the North Pacific, Mar. Micropaleontol., 5, 329-399.

Geraga M., Tsaila-Monopolis St., Ioakim Chr., Papatheodorou G. and Ferentinos G. 2005. Shortterm climate changes in the southern Aegean Sea over the last 48000 years, Palaeogeogr. Palaeoclimatol. Palaeoecol., 220, 311-332.

Hemleben C., Spindler M. and Erson O.R. 1989. Modern Planktonic Foraminifera, Springer, Berlin, $363 \mathrm{pp}$.

Jorissen F.J., Asioli A., Borsetti A.M., Capotondi L., de Visser J.P., Hilgen F.J., Rohling E.J., van der Borg K., Vergnaud Grazzini C. and Zachariasse W. 1993. Late Quaternary central Mediterranean biochronology, Mar. Micropal., 21, 169-189.

Kennett J. 1982. Marine Geology, Prentice-Hall Inc, Englewood Cliffs, 538-559.

Kontakiotis G. 2012. Palaeoceanographic and palaeoclimatic study of Eastern Mediterranean during Late Quaternary, based on planktonic foraminiferal assemblages, PhD Thesis, National \& Kapodistrian University of Athens, Greece, pp. 1-247.

Pujol C. and Vergnaud-Grazzini C. 1995. Distribution patterns of live planktic foraminifers as related to regional hydrography and productive systems of the Mediterranean Sea, Mar. Micropal. 25, 187-217.

Rohling E.J., Jorissen F.J. and De Stigter H.C. 1997. 200 year interruption of Holocene sapropel formation in the Adriatic Sea, J. Micropal., 16, 97-108.

Rohling E.J., Jorissen F.J., Vergnaud-Grazzini C. and Zachariasse W.J. 1993. Northern Levantine and Adriatic Quaternary planktic foraminifera: Reconstruction of paleoenvironmental gradients, Mar. Micropaleontol., 21, 191-218.

Triantaphyllou M.V., Antonarakou A., Dimiza M. and Anagnostou Ch. 2010. Calcareous nannofossil and planktonic foraminiferal distributional patterns during deposition of sapropels S6, S5 and S1 in the Libyan Sea (Eastern Mediterranean), Geo-Mar. Lett., 30(1), $1-13$.

Triantaphyllou M.V., Antonarakou A., Kouli K., Dimiza M., Kontakiotis G., Papanikolaou M.D., Ziveri P., Mortyn P.G., Lianou V., Lykousis V. and Dermitzakis M.D. 2009. Late GlacialHolocene ecostratigraphy of the south-eastern Aegean Sea, based on plankton and pollen assemblages, Geo. Mar. Lett., 29(4), 249-267.

Zachariasse W.J., Jorissen F.J., Perissoratis C., Rohling E.J. and Tsapralis V. 1997. Late Quanternary foramineteral changes and the nature of sapropel S1 in Skopelos Basin, $5^{\text {th }}$ Hell. Symp. Oceanogr. Fish, NCMR Athens, Procceedings, 1, 391-394. 